\title{
Mobile Phosphorus and Exchange Potassium of Typical Black Soil in Long-Term use of Arable Land
}

\author{
Karabutov A.P., Tyutyunov S.I, Solovichenko V.D.
}

\begin{abstract}
The influence of crop rotations, soil treatment methods and fertilizers on the content and balance of mobile phosphorus and exchange potassium in black soil was tested. Over the 25-year period of typical black soil use the content of mobile phosphorus increased not only under the influence of fertilizers, but also without them. The greatest impact was made by fertilizers, less significantly by crop rotations and methods of basic soil treatment. An increase in the content of mobile phosphates is observed among the tested crop rotations in grain fallow row, and from the methods of soil treatment - for small-scale processing.

For five rotations of crop rotations without fertilizers, there were no significant changes in the content of exchange potassium; it remained at the level of increased security. Mineral fertilizers in double doses against the background of manure increased the content of exchangeable potassium to a high level of security. The saturation of crop rotations with row crops, as well as the use of plowing increases the content of exchangeable potassium, but to a lesser extent than fertilizers.
\end{abstract}

The intensity balance of phosphorus is changed by the rotation of the crop rotation unevenly, which is associated with the magnitude of crop yield and, consequently, the removal of this element. At the same time, the general pattern of correspondence between the increase in the intensity of the balance with the increase in fertilizer application remains.

Positive balance of potassium is provided only at double doses of mineral fertilizers. Manure creates a balance intensity of only 39\%, which is 2.6 times less than fertilizers. Application of N42-62P62K62 against the background of $16 \mathrm{t} / \mathrm{ha}$ of manure leads to an increase in the balance intensity of more than $80 \%$.

Keywords: long-term field experience, mobile phosphorus, exchange potassium, crop rotation, fertilizers, soil treatment techniques.

\section{INTRODUCTION}

One of the main biogenic elements in nature are phosphorus and potassium. Phosphorus in soils is in mineral and organic compounds. Its total content in the arable layer of black soils is $0.2-0.3 \%$ [6]. At the same time, only $10-20 \%$ of its amount is represented by relatively accessible

Revised Manuscript Received on July 22, 2019

Karabutov A.P., Candidate of Agricultural Sciences (Ph.D.), Research Officer, Belgorod Federal Agricultural Research Center of RAS

Tyutyunov S.I, Doctor of Agricultural Sciences (Advanced Doctor), Director, Belgorod Federal Agricultural Research Center of RAS

Solovichenko V.D., Doctor of Agricultural Sciences (Advanced Doctor), Heads of Laboratory, Belgorod Federal Agricultural Research Center of RAS compounds to plants. It is known that the content of mobile phosphates, the degree of their mobility and availability for plants increases with the use of phosphorus fertilizers [4]. In some works $[3,7,10$, etc.] efficiency of phosphoric fertilizers on black soils is shown. Normal phosphorus nutrition accelerates the development of crops, increases their cold resistance and drought resistance, promotes stronger grain formation in cereals and improves the quality of the crop [8; 28].

Studies in the forest-steppe of the Central black earth region found that, as a rule, the content of mobile forms of phosphorus in the soil increases with the introduction of phosphorus fertilizers. On typical black soil of Belgorod region the content of acid-soluble phosphorus and the degree of its mobility without fertilization for 2 rotations of 5 -field crop rotation remained at the initial level. The use of full mineral fertilizer increased significantly these indicators, and, to a depth of $60 \mathrm{~cm}$. At the same time, it was found that in the fractional composition of phosphates there was an increase in the fraction of phosphates associated with iron and a decrease in the amount of phosphates associated with calcium [1].

In leached black soil of Voronezh region under the influence of 70-year application of mineral fertilizers and manure there was an increase in the amount of gross phosphorus, as well as $\mathrm{P} 2 \mathrm{O} 5$ extracted with $0.5 \mathrm{n}$. acid and $3.0 \mathrm{n}$. alkali. At the same time, there was a decrease in the content of non-extracted phosphorus from the soil, and the absorption of phosphates by the soil itself [5].

Potassium is one of the main, along with phosphorus, essential elements of mineral nutrition of plants. The presence of potassium in the soil is associated with its granulometric composition - the heavier it is, the more it contains gross and mobile potassium. When potassium enters the soil with fertilizers, including black soil, there is its exchange and partially non-exchange absorption. The peculiarity of the potash regime of soils is the presence of a constant dynamic balance between different forms of potassium $[11 ; 26 ; 27]$.

Arable black soils of the Central black soil region at the present stage of their use are relatively provided with mobile forms of potassium (on average about $110 \mathrm{mg} / \mathrm{kg}$ of soil). However, to stabilize the potash regime of black soils, the authors [12] believe that it is necessary to increase the supply of this element to agricultural

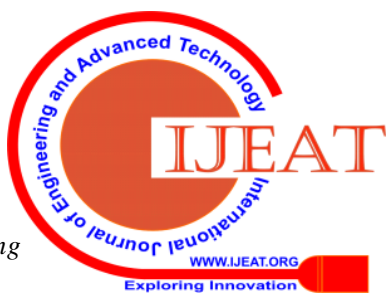


landscapes and increase the intensity of the balance to $80 \%$.

Potash fertilizers are the main factor in increasing the content of potassium available to plants. If this role is underestimated on black soils, its intensive mobilization from non-exchange forms occurs [13; 21-24],

which subsequently leads to a negative balance of the element, and as a consequence to a decrease in crop yields. Potassium mobilization can occur not only from its non-exchange forms, but also aluminosilicates, which reduces the buffer capacity of the soil, destroys the soil absorbing complex. It should be borne in mind that when applying fertilizers on black soil, there is a transition of potassium introduced into a non-exchangeable form, and as a result, the content of its mobile forms in the soil increases slightly [14-20].

These circumstances necessitate the search for methods to optimize the phosphorus-potassium regime, to ensure the intensity of the balance of phosphorus and potassium and increase the productivity of cultivated crops.

The purpose of this study is to establish the regime of mobile forms of phosphorus and exchange potassium in typical black soil for long-term testing of agricultural techniques. At the same time, the following tasks were solved: to determine the change in the content of mobile phosphorus and exchange potassium in the soil under the influence of fertilizers, crop rotations and soil treatments, to calculate the intensity of the balance of phosphorus and potassium compounds in the system: fertilizers - soil - plant and to determine the impact of agricultural techniques on the productivity of crop rotations.

\section{RESEARCH METHODS}

The studies were conducted in the laboratory of soil fertility and monitoring of the Belgorod Research Institute of Agriculture in the field multifactorial stationary experience, founded in 1987.

The soil of the experimental site is black soil typical medium powerful low humus heavy loam on loess-like loam. The humus content (according to Tyurin) at the time of the experiment was in the layer of $0-30 \mathrm{~cm} 5.27-5.36 \%$, total nitrogen (according to Kjeldal) - 0.29-0.31\%, alkaline hydrolyzed nitrogen (according to Cornfield) - 151-163 $\mathrm{mg} / \mathrm{kg}$ of soil, mobile phosphorus and potassium (according to Chirikov), respectively - 45-71 and $90-106 \mathrm{mg} / \mathrm{kg}$ of soil, $\mathrm{pHKCl}-5.6-5.8$, the degree of saturation of the bases about $90 \%$.

The phosphorus-potassium regime of the soil was studied under the influence of factors: crop rotations (A), soil treatment techniques (B) and fertilizers (C). Crop rotations differ in the saturation of row crops (sugar beet and corn): $20 \%$ of the area in grain grass row, $40 \%$ - in grain row and $80 \%$ in grain fallow row. Methods of basic soil treatments: plowing to a depth of $22-27 \mathrm{~cm}$, chisel loosening to the same depth and small soil treatment to a depth of $10-12 \mathrm{~cm}$. The scheme with fertilizers represented: control (without fertilizers), application of fertilizer, manure, and their joint application. Doses of fertilizers are designed for simple and expanded reproduction of soil fertility. Litter manure of cattle was introduced once for rotation of crop rotations under sugar beet.

Mobile phosphorus and exchange potassium were determined by Chirikov (GOST 26204-91), the intensity of the balance of elements by the calculation method, statistical processing of the results of studies by B.A. Dospekhov [2]

\section{RESULTS AND THEIR DISCUSSION}

According to the results, the content of mobile phosphorus in the soil increased significantly over the 25-year period. Among the tested agronomic techniques, fertilizers had the greatest impact, much less crop rotations and basic soil treatment techniques. The data show that in all variants of the experiment there is an increase in the content of mobile phosphorus from rotation to rotation (table 1).

Table- I: Changes in the mobile phosphorus content (P2O5) in the soil layer of 0-30 cm depending on agricultural techniques, $\mathrm{mg} / \mathrm{kg}$

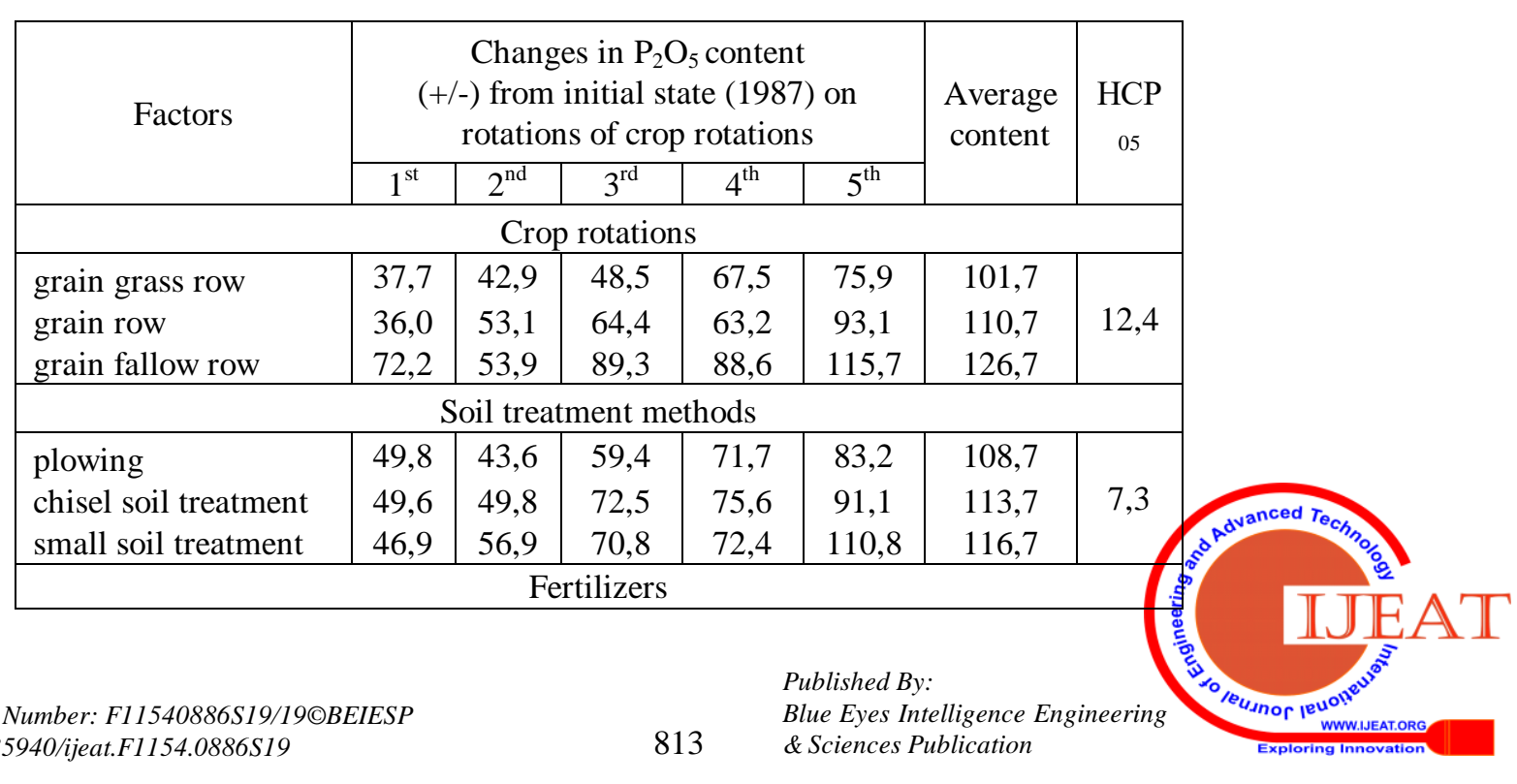




\begin{tabular}{|c|c|c|c|c|c|c|c|}
\hline $\begin{array}{l}\text { Without fertilizers, } \\
\text { control }\end{array}$ & 6,6 & 16,9 & 13,1 & 26,6 & 27,8 & 64,2 & \multirow{9}{*}{9,1} \\
\hline N42-62P62K62 & 45,5 & 39,5 & 55,4 & 58,7 & 71,2 & 104,1 & \\
\hline N84-124P124K124 & 70,1 & 66,5 & 94,1 & 112,2 & 132,6 & 139,6 & \\
\hline Field $1-8 \mathrm{t}$ of manure & 15,2 & 19,1 & 23,6 & 29,5 & 40,2 & 71,1 & \\
\hline $\begin{array}{l}\text { Field } 1+ \\
\text { N42-62P62K62 }\end{array}$ & 45,3 & 44,4 & 66,3 & 56,9 & 96,7 & 111,0 & \\
\hline $\begin{array}{l}\text { Field 1+ } \\
\text { N84-124P124K124 }\end{array}$ & 88,8 & 90,8 & 119,0 & 120,3 & 139,4 & 159,0 & \\
\hline $\begin{array}{l}\text { Field } 2-16 \mathrm{t} \text { of } \\
\text { manure }\end{array}$ & 36,3 & 30,2 & 35,7 & 38,6 & 59,4 & 86,1 & \\
\hline $\begin{array}{l}\text { Field } 2+\text { N42-62 } \\
\text { P62K62 }\end{array}$ & 49,5 & 61,7 & 73,6 & 86,8 & 125,8 & 122,5 & \\
\hline $\begin{array}{l}\text { Field } 2+\text { N84-124 } \\
\text { P124K124 }\end{array}$ & 80,1 & 80,4 & 125,9 & 128,2 & 161,0 & 159,7 & \\
\hline
\end{tabular}

According to the data, the increase in mobile phosphorus occurred in the control version of the experiment, where fertilizers were not introduced. A similar phenomenon is associated with the influence of acidic precipitation [9]. The content of mobile phosphorus increased significantly at the control after the $4^{\text {th }}$ rotation of crop rotations.

Let us consider the change in the content of mobile phosphorus by factors. During the studies among the types of crop rotations, the content of $\mathrm{P}_{2} \mathrm{O}_{5}$ increased most in the grain fallow row crop rotation, as evidenced by the results of statistical processing. Grain grass row and grain row crop rotations have almost the same phosphate content at the end of the $5^{\text {th }}$ rotation. Their content also increased among methods of main treatment, but more influenced by small soil treatment, which was proved mathematically. Fertilizers contributed to the increase in the content of mobile phosphorus as the duration of their application. At the same time, the introduction of manure in a dose of $8 \mathrm{t} / \mathrm{ha}$ of crop rotation area practically does not provide an increase in the average content of mobile phosphates compared to the control. For other fertilized variants, it can be noted that the increase in the phosphorus content was directly dependent on the dose of the applied fertilizers. In general, it can be concluded that the content of mobile phosphates in the soil increased with the testing duration of agricultural practices and even without fertilizer.

The content of exchange potassium in the soil layer of $0-30$ $\mathrm{cm}$ before laying the experiment was increased; it did not change after five rotations of crop rotations without fertilizers. Separate or combined application of mineral fertilizers and manure increased the content of available potassium, and double doses created a high degree of security (table 2).

Crop rotations and soil treatment techniques contribute to an increase in the content of mobile potassium. Among the crop rotations grain row and grain fallow row stand out and soil treatment methods - plowing. Plowing obviously increases the content of exchange potassium, helping to mobilize it from non-exchange forms.

Table- II: Change in the content of exchange potassium (K2O) in the soil layer of 0-30 cm depending on agricultural techniques, $\mathrm{mg} / \mathrm{kg}$

\begin{tabular}{|c|c|c|c|c|c|c|c|}
\hline \multirow[t]{2}{*}{ Factors } & \multicolumn{5}{|c|}{$\begin{array}{c}\text { Changes in } \mathrm{K}_{2} \mathrm{O} \text { content }(+/-) \text { from initial state } \\
\text { (1987) on rotations of crop rotations }\end{array}$} & \multirow{2}{*}{$\begin{array}{l}\text { Average } \\
\text { content }\end{array}$} & \multirow[t]{2}{*}{$\mathrm{HCP}_{05}$} \\
\hline & $1^{\mathrm{st}}$ & $2^{\text {nd }}$ & $3^{\text {rd }}$ & $4^{\text {th }}$ & $5^{\text {th }}$ & & \\
\hline \multicolumn{8}{|c|}{ Crop rotations } \\
\hline grain grass row & 20,0 & 4.9 & $-17,0$ & 17,0 & $-0,7$ & 98,0 & \multirow{3}{*}{11,5} \\
\hline grain row & 21,2 & 10,7 & 9,1 & 17,3 & 22,7 & 111,6 & \\
\hline grain fallow row & 6,9 & $-7,6$ & 11,3 & 31,6 & 39,3 & 114,1 & \\
\hline \multicolumn{8}{|c|}{ Soil treatment methods } \\
\hline plowing & 21,5 & 4,3 & 2,5 & 27,4 & 28,2 & 112,5 & \multirow{3}{*}{4,5} \\
\hline chisel soil treatment & 19,1 & 4,6 & 1,4 & 20,1 & 17,5 & 106,5 & \\
\hline small soil treatment & 6,9 & $-0,9$ & $-0,6$ & 18,4 & 15,5 & 104,7 & \\
\hline \multicolumn{8}{|c|}{ Fertilizers } \\
\hline Without fertilizers, control & $-3,1$ & $-7,3$ & $-16,0$ & 3,1 & $-4,6$ & 88,9 & \multirow{4}{*}{5,8} \\
\hline N42-62P62К62 & 5,4 & $-5,1$ & $-9,0$ & 11,7 & 7,3 & 95,7 & \\
\hline N84-124P124K124 & 11,9 & 6,4 & 0,3 & 27,5 & 23,7 & 108,6 & \\
\hline Field $1-8 \mathrm{t}$ of manure & 5,4 & $-8,2$ & $-4,0$ & 13,5 & 12,4 & 98,2 & \\
\hline
\end{tabular}




\begin{tabular}{|l|c|c|c|c|c|c|c|} 
Field 1 + N42-62P62K62 & 6,1 & $-2,1$ & 1,8 & 16,3 & 11,7 & 105,9 & \\
Field 1+ N84-124P124K124 & 28,7 & 16,1 & 20,5 & 33,2 & 35,0 & 126,6 & \\
Field 2 - 16 t of manure & 17,6 & $-3,0$ & $-1,9$ & 17,0 & 14,0 & 101,6 & \\
Field 2 + N42-62 P62K62 & 30,0 & 6,2 & 0,6 & 31,1 & 33,3 & 114,8 & \\
Field 2 + N84-124 & 44,1 & 22,0 & 18,7 & 45,0 & 51,9 & 131,0 & \\
\hline
\end{tabular}

Calculation of the intensity of the balance of phosphorus and potassium indicates the important role of fertilizers in the regulation of mobile forms of phosphorus and potassium in the system: fertilizer - soil - crop (table 3).

Table- III: Intensity of phosphorus and potassium balance and crop rotation productivity depending on agricultural techniques

\begin{tabular}{|c|c|c|c|c|c|}
\hline \multirow{2}{*}{\multicolumn{2}{|c|}{ Factors }} & \multirow{2}{*}{$\begin{array}{c}\text { Intensity of } \\
\text { phosphorus balance } \\
, \%\end{array}$} & \multirow{2}{*}{$\begin{array}{c}\text { Intensity of } \\
\text { potassium balance } \\
\%\end{array}$} & \multicolumn{2}{|c|}{$\begin{array}{c}\text { Crop rotation productivity, } \\
\text { t/ha }\end{array}$} \\
\hline & & & & grain units & $\begin{array}{l}\text { digestible } \\
\text { protein }\end{array}$ \\
\hline \multicolumn{6}{|c|}{ Crop rotations } \\
\hline grain grass row & & 242,8 & 80 & 22,2 & 2,59 \\
\hline grain row & & 244,9 & 90 & 24,2 & 2,12 \\
\hline grain fallow row & & 240,8 & 75 & 25,8 & 1,93 \\
\hline \multicolumn{6}{|c|}{ Soil treatment methods } \\
\hline plowing & & 241,4 & 80 & 24,3 & 2,22 \\
\hline chisel soil treatme & & 242,3 & 81 & 24,2 & 2,22 \\
\hline small soil treatme & & 244,8 & 83 & 23,7 & 2,20 \\
\hline \multicolumn{6}{|c|}{ Fertilizers } \\
\hline Without fertilizers & & 2,8 & 2 & 16,8 & 1,62 \\
\hline N42-62P62K62 & & 215,1 & 73 & 23,1 & 2,12 \\
\hline N84-124P124K12 & & 380,2 & 128 & 26,0 & 2,37 \\
\hline Field $1-8 \mathrm{t} / \mathrm{ha}$ of & & 81,0 & 28 & 19,8 & 1,86 \\
\hline Field $1+\mathrm{N} 42-62$ & & 260,5 & 88 & 25,1 & 2,29 \\
\hline Field $1+\mathrm{N} 84-12$ & & 414,3 & 138 & 27,6 & 2,52 \\
\hline Field $2-16 \mathrm{t} / \mathrm{ha}$ & & 146,8 & 50 & 21,6 & 2,01 \\
\hline Field $2+\mathrm{N} 42-62$ & & 243,1 & 81 & 27,0 & 2,45 \\
\hline Field $2+\mathrm{N} 84-12$ & & 441,9 & 146 & 29,8 & 2,69 \\
\hline \multirow{3}{*}{$\mathrm{HCP}_{05}$ on factors: } & A & 14,5 & 4,9 & 0,8 & 0,16 \\
\hline & B & 3,2 & 1,2 & 0,4 & 0,03 \\
\hline & $\mathrm{C}$ & 6,7 & 2,2 & 0,5 & 0,05 \\
\hline
\end{tabular}

Crop rotations among themselves did not differ in the balance of phosphorus, and among the methods of soil treatment, small soil treatmnet has the highest average value of the intensity of the balance. Cultivation of crops without fertilizers creates a sharp balance of mobile phosphorus compounds. Application of manure in a dose designed for simple reproduction of soil fertility ( $8 \mathrm{t} / \mathrm{ha}$ of crop rotation area) provides a low balance of phosphorus compounds. Mineral fertilizers, both by themselves and introduced together with manure, create a high intensity of phosphorus balance in the soil.

Crop rotation, methods of soil treatment and fertilizer influence the intensity of potassium balance. The balance of potassium in a greater degree depends on applied fertilizer. Positive balance was provided only at double doses of mineral fertilizers. On average, the application of mineral fertilizers provides a balance intensity of about $101 \%$, while the introduction of manure only $39 \%$, i.e. by 2.6 times less than mineral fertilizers. The greatest positive balance of potassium was observed in the joint application of double doses of fertilizers and manure, where the intensity was equal to an average of $142 \%$.

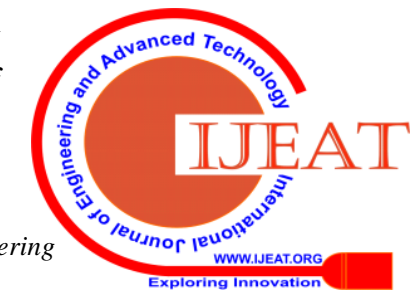


The intensity of the balance is reduced in the grain fallow row crop rotation relative to the grain row by 1.2 times. It is noted that among the tested methods of soil treatment plowing helps to reduce the intensity of potassium balance.

The balance of phosphorus and potassium associated with the productivity of cultures of crop rotation. The results of studies show that the largest collection of grain units provides grain fallow row crop rotation, despite the fact that one field of crop rotation annually does not produce anything. The collection of grain units here was 1.2 times higher than in the grain grass row crop rotation. At the same time, on the collection of digestible protein grain grass row crop rotation is more productive than grain fallow row by 1.3 times due to sainfoin participation in the rotation.

Mineral fertilizers increased the collection of grain units and digestible protein by an average of 1.5 times in relation to the control, and manure by 1.2 times.

Application of double doses of fertilizers and manure leads to a maximum increase in crop productivity. So the collection of grain units and digestible protein increased by 1.7-1.8 times in relation to control.

\section{CONCLUSION}

The main factor in optimizing the phosphorus-potassium regime of black soils and obtaining the highest productivity of crops is the introduction of mineral fertilizers together with manure. Saturation of crop rotations with row crops increases the content of mobile phosphorus and exchange potassium and the collection of grain units, and saturation with perennial grasses - the intensity of the balance of phosphorus and potassium and the collection of digestible protein. Plowing increases the content of exchange potassium, and small soil treatment - mobile phosphorus.

\section{REFERENCES}

1. Voronin A.N. Effect of prolonged application of fertilizers on the phosphate regime of typical black soil / A.N. Voronin, V.V. Nikitin, V.D. Solovichenko // Agrochemistry.- 2015. - № 3. - P. 17-20.

2. Dospekhov B.A. Methods of field experience / B.A. Dospekhov. -5 th ed. - M.: Agropromizdat, 1985. - 351 p.

3. Kurakov V I. Fertility of leached black soil with long-term use of fertilizers / V.I. Kurakov, O.A. Minakova, V.V. Sitnikova, L.V. Alexandrova // Fertility. - 2006. - № 1. - P.8-9.

4. Makarov R.F. Optimization of the food regime of typical Chernozem in connection with the intensification of agriculture: autoref. of diss. Doctor of Agricultural Sciences: 06.01.04 / VIAU. - M., 1990. - 36 p.

5. Minakova O.A. Agroecological aspects of fertilizer application in grain-pasture crop rotation of the forest-steppe of the CBSR: autoref. of dis. Doctors of Agricultural Sciences: 06.01.04 / VSAU. - Voronezh, 2011. -48 p.

6. Agricultural chemistry: textbook / V.G. Mineev. - Moscow: Publishing house of Moscow University, 2006. - 719 p.

7. Nikitin V.V. Evaluation of factors of crop rotation productivity / V.V Nikitin, A.P. Karabutov, etc. // Agriculture. - 2013. - № 1. - P. 12-14.

8. Plant growing: a textbook / G. S. Posypanov, V.E. Dolgodvorov, etc.; Under the ed. of G.S. Posypanov. - M.: Kolos, 2006. -612 p.

9. Sokorev N.S. Agroecological justification of the effectiveness of long-term use of mineral fertilizers on leached black soil of Central black soil region depending on the availability of phosphorus: autoref. of dis. Doctor of Agricultural Sciences: 06.01.03 / RRIASPE, - Kursk, 2006. $42 \mathrm{p}$.
10. Shcherbakov A.P. Soil fertility, circulation and nutrient balance / A.P Shcherbakov, I.D. Ruday - M.: Kolos. 1983. - 189 p.

11. Brekhov P.T., Mazin N.G. Forms of potassium in the typical black soil at long application of fertilizers // Agrochemical messenger. 2012. №4. P. 5-7.

12. Chekmarev P.A., Lukin S.V. Monitoring of the potassium regime of chernozems of the CBSR // Achievements of science and technology of agriculture. 2011. №8. P. 3-5

13. Davlyatshin I.D., Lukmanov A.A., Badikov A. Potassium in arable soils of forest-steppe //Soil fertility. 2013. №2. P. 27-28.

14. Rakov A. Yu., Sirota M.A. Exchange potassium as a limiting factor of crop yield // Agriculture. 2013. №7. P. 31-32.

15. Prokoshev V.V. Potash fertilizers. Value, production, application, ecology // International Potassium Institute (IPI). - 1994. - 67p.

16. Yakimenko V.N. Changes in the content of potassium forms on the soil profile at different potash balance in agrocenoses // Agrochemistry. 2007 №3. P. 5-11.

17. Rogova O.B., Kolobova N.A., Ivanov A.L. Phosphorus Sorption Capacity of Gray Forest Soil as Dependent on Fertilization System / Eurasian Soil Science. 2018. Vol. 51. № 5. P. 536-541.

18. EU Environment Directorate. Phosphates and Alternative Detergent Builders - Final Report. Wre Ret: UC 4011 yune, 2002. - 334 p.

19. F. N. Lisetskii, V. K. Tokhtar, V. M. Ostapko, S. A. Prykhodko and T. V. Petrunova Regularities and Features of Differentiation and Anthropogenic Transformation of Steppe Vegetation / Terrestrial Biomes: Geographic Distribution, Biodiversity and Environmental Threats. Editors: Marlon Nguyen. USA, Nova Science Publishers, Inc., 2016. Chapter 4. pp. 103-126.

20. Gusev, A.V., Lisetskii, F.N., Ermakova, E.I. Principles and experience of justification of ecological representativeness of Emerald network potential sites /Research Journal of Pharmaceutical, Biological and Chemical Sciences. India, Volume 7, Issue 2, 2016, Pages 1172-1189

21. Kiryushin V.I. Ecological Functions of Landscapes / Eurasian Soil Science. 2018. Vol. 51. № 1. P. 14-21.

22. Dubovik E.V., Dubovik D.V. Relationships between the Organic Carbon Content and the Structural State of Typical Chernozem /Eurasian Soil Science. 2019. № 2. P. 171-183.

23. Smirnova L.G., Chendev Y.G., Kukharchuk N.S., Narozhnaya A.G., Kukharuk S.A., Smirnov G.V. Changes in soil Cover Due to Short-Period Climatic Variations /Eurasian Soil Science. 2019. № 7. P. 773-780.

24. Semenov V.M., Zinyakova N.B., Lebedeva T.N., Tulina A.S., Kogut B.M., Masyutenko N.P., Malyukova L.S. Biologically Active Organic Matter in Soils of European Russia / Eurasian Soil Science. 2018. Vol. 51. № 4. P. 434-447.

25. Chendev Y.G., Petin A.N., Sarapulkin V.A., Aleksandrovskii A.L., Khokhlova O.S., Dergacheva M.I., Golotvin A.N., Uvarkin S.V., Zemtsov G.L. Evolution of forest pedogenesis in the south of the forest-steppe of the Central Russian Upland in the Late Holocene Eurasian Soil Science. 2017. Vol. 50. № 1. P. 1-13.

26. Lebedeva I.I., Grebennikov A.M., Markina L.G., Cheverdin Y.I., Titova T.V. Structural state of migrational-mycelial (typical) agrochernozems of the Kamennaya Steppe on plowed fields of different ages Eurasian Soil Science. 2017. Vol. 50. № 2. P. 218-228.

27. Chendev Y.G., Khokhlova O.S., Alexandrovskiy A.L.Agrogenic evolution of automorphic chernozems in the forest-steppe zone (Belgorod oblast) / Eurasian Soil Science. 2017. Vol. 50. № 5. P. 499-514. 